IZA DP No. 7352

The Making of Middle Class in Africa:

Evidence from DHS Data

Mthuli Ncube

Abebe Shimeles

April 2013 


\title{
The Making of Middle Class in Africa: Evidence from DHS Data
}

\author{
Mthuli Ncube \\ African Development Bank
}

Abebe Shimeles

African Development Bank

and IZA

\author{
Discussion Paper No. 7352 \\ April 2013
}

\author{
IZA \\ P.O. Box 7240 \\ 53072 Bonn \\ Germany \\ Phone: +49-228-3894-0 \\ Fax: +49-228-3894-180 \\ E-mail: iza@iza.org
}

Any opinions expressed here are those of the author(s) and not those of IZA. Research published in this series may include views on policy, but the institute itself takes no institutional policy positions. The IZA research network is committed to the IZA Guiding Principles of Research Integrity.

The Institute for the Study of Labor (IZA) in Bonn is a local and virtual international research center and a place of communication between science, politics and business. IZA is an independent nonprofit organization supported by Deutsche Post Foundation. The center is associated with the University of Bonn and offers a stimulating research environment through its international network, workshops and conferences, data service, project support, research visits and doctoral program. IZA engages in (i) original and internationally competitive research in all fields of labor economics, (ii) development of policy concepts, and (iii) dissemination of research results and concepts to the interested public.

IZA Discussion Papers often represent preliminary work and are circulated to encourage discussion. Citation of such a paper should account for its provisional character. A revised version may be available directly from the author. 


\section{ABSTRACT \\ The Making of Middle Class in Africa: Evidence from DHS Data}

This paper presents evidence on the making of the middle class in Africa by exploiting a comparable micro data from the Demographic and Health Surveys (DHS) for thirty-seven countries over two decades consisting of over seven hundred thousand household histories. We constructed a pseudo-panel to examine the dynamics of middle class in blocks of four periods covering the period 1990-2011. A key finding is that there was significant mobility of the middle class to the upper class in the last two decades with very few slipping back to poverty with obvious difference across countries. The paper approached the making of a middle class in Africa from institutional and policy perspectives. Initial conditions such as level of development in early decades, quality of institutions and most of all ethnic fractionalization play a significant role in determining the growth of the middle class in recent years. In addition we found evidence suggesting that the size of the middle class is higher in countries where mutual trust among citizens tends to be stronger. The role of education feature prominently in the making of the middle class. In about 30 of the 83 country-level regression decompositions we conducted for the asset index, the contribution of education exceeded $25 \%$ in explaining the overall variance in the asset index. The 'premium' (or 'return') individuals obtain from achieving primary, secondary and tertiary level of education is unambiguously high compared with no education, but the effect decreases as the mean level of schooling increases.

JEL Classification: D31, J15

Keywords: middle class, asset index, multiple correspondence analysis, regression decomposition

Corresponding author:

Abebe Shimeles

African Development Bank

Research Department (EDRE)

P.O. Box 323

1002 Tunis Belvédère

Tunisia

E-mail: a.shimeles@afdb.org 


\section{Introduction}

Recent interest in understanding and analyzing the evolution of the middle class in the context of developing countries is inspired partly by economic successes in Asia and Latin America where the emerging middle class has played a major role in driving growth (Desgoigts and Jaramillo, 2009; Easterly, 2001; Chun, 2010) and the historical evidence in the 19th century Europe and North America where the middle class was a major force in the process of development( Adelman and Morris, 1997; Landes, 1998). Recent discussions also highlighted the role of the middle class as a conduit for advancing social progress (e.g Sridharan, 2004) possibly an agent of change constantly reforming institutions (Loyza et al, 2012) and promoting democracy (Petterson, 2007). It is also argued that burgeoning middle class can be a catalyst for the realization of inclusive growth (Birdsall, 2010), antidote to combating chronic poverty through hard work (Dyan, 1997), innovation and entrepreneurial drive (Barnejje and Duclo, 2009). Despite these overwhelming evidence on the all-encompassing role attributed to the middle class, very little is known about its size and attributes in Africa until recently (AfDB, 2011; McKenzie, 2010).

This study builds on previous work to provide further evidence on the making of the middle class but differs in the following ways. First, it proposes to use asset or wealth status reported in the Demographic and Health Surveys (DHS) instead of income or consumption expenditure as a key indicator to identify the population of the middle class. This approach has several advantages. Asset or wealth status reported in DHS is not only better measured than consumption (Moser and Felton, 2007), but also designed carefully to be comparable over time and across countries. Comparatively it is also available for many countries in multiple waves. In addition, most of the countries covered in this study do not have well developed financial systems by which savings from earnings can be translated into investment or borrowing against future earnings are available to smooth consumption. Assets are built often by drawing down cash savings. Household asset are accumulated in part as buffer against shocks and also as a way of improving standard of living (tap water, better roofs, floors, bedrooms, etc). Given the predominance of food in total expenditure in a number of African countries, much of the factors commonly believed to constitute a middle class status are easily missed. Furthermore, the data on asset ownership is based on a wide range of indicators offering greater opportunity to capture a broader meaning of the middle class.

Secondly, this study goes further in examining the factors driving crosscountry differences as well as in providing household and individual characteristics correlated with the middle class characteristics using unit record data covering 37 African countries with multiple data points. The total sample size used for such analysis consisted of the history of over 750,000 house- 
holds. It also utilizes carefully constructed synthetic or pseudo panel from this sample to examine the dynamics of the middle class across cohort. Finally the paper presents a discussion on what drives the making of the middle class in Africa. Institutional and policy aspects are pursued in great length. Particularly the role of ethnic fractionalization and level of trust among citizens in assisting social mobility is examined. With respect to policy we focus on governance, education and health as main pathways into nurturing the middle class using unit record data and a synthetic panel constructed from the individual country surveys.

Our result is informative and revealing. The size of the middle class increased in the last decade in most African countries. There are however notable differences. It increased in 21 of the countries in our sample while it decreased in others (4) for which we have multiple observations over the period. In some cases the rise is dramatic. The factors that led to the changes could be broadly classified into those of asset shrinking (average asset index declined), or rising asset inequality, or rapid asset accumulation. Country cases are provided to illustrate these patterns.

The cross-country variation in the size of the middle class is explained largely by differences in initial conditions, social structure (mainly ethnic fractionalization and the degree of mutual trust among citizens), size of government and most of all the degree of asset inequality. Generally, countries that have homogenous ethnic groups, stronger social capital as captured by mutual trust, bigger government, and high initial level of development tend to have higher size of the middle class. These results very much echo previous studies for other regions (Knack and Keffer, 1997) and Easterly (2002) for developing world.

Findings from analysis of multiple country level household surveys indicate that individuals in the middle class tend to be well educated and the 'returns' to education in terms of higher asset accumulation are consistently higher for all level of education than no education at all. What would be the implications of expanding education opportunities as a policy to promote the middle class? This has to be seen cautiously as the 'returns' to additional level of education declines with stock of educated people at secondary and tertiary levels while it remains unchanged for primary education. The decline is intuitive since an increase in 'supply' leads to a decline in 'price' for a 'given demand'. But, it should also be welcome as it could lead to a decline in overall inequality by narrowing down relative differences across the education spectrum. The rest of the paper is organized as follows. Section 2 describes data and methodology, Section 3 presents the key results and Section 4 concludes the paper. 


\section{Data and methods}

\subsection{Definition of middle class using asset Index from DHS data}

So far the evidence reported on the size of the middle class in Africa relied mainly on consumption expenditure aggregates drawn from household surveys. The most popular source is World Bank's povcalnet which makes available grouped distributional data along with mean consumption expenditure. For African countries the data covers the period 1981-2008 over 9 data points which started initially with one country in 1981 and subsequently ended up covering 44 countries. Evidently, distributional information in early years was imputations drawn from few available surveys. In this study we report results mainly based on unit record data from the Demographic Health Survey for 42 countries compiled over the period 1990-2011 (see Annex Table 1). The drawback of the DHS is that there are very few countries covered in a typical year. In our analysis we combined periods in blocks of five years [pre1995, 1995-2000, 2000-2005 and 2005-2011] to capture the size of the middle class which arguably is a strong assumption but necessary given the paucity of such data in Africa.

The strength of the DHS data set is that it provides a wide range of information on household and individual wellbeing, including basic social and demographic characteristics. In defining the middle class we have used responses to 11 questions regarding source of water for the household (such as pipe water, tap water, water kiosk and well, etc.), condition of housing (number of rooms, floor material-perke, cement, ceramic, earth-, roof material-bricks, tin, grass, earth, etc.), ownership of durable assets-radio, television, telephone, refrigerator, car, etc. The challenge for us is to generate a single composite asset index with appropriate weighting and measure the size of the middle class for each country covered in the study. The following construct makes the assignment clear. Let $W_{j}$ is a welfare measure for an individual $j$ defined over a set of variables $c_{i}$ with a property that :

$$
W_{j}=\sum_{i=1}^{k} a_{i} c_{i j}
$$

Where the $i$ represents the $k$ assets that individual $j$ possesses at a point in time to achieve a welfare level $W_{j}$, which could be cardinal or unit free (ordinal) depending on how the components enter the welfare measure. The linearity in (1) assumes that the welfare is additive over the constituents (in our case the individual assets) allowing a possibility for a perfect substitution across the individual assets. The marginal rate of substitution is given by the ratios of the $a_{i}$ parameters that would keep a constant welfare level. It measures how much of unit of $c_{i}$ be given up in relation to $c_{k}$ to keep the welfare level unchanged. It is also the weight by which each of the assets contributes 
to the overall welfare ${ }^{1}$. To get the intuition, let us take a case where $W$ is total consumption expenditure over $c_{i}$ commodities. Then, evidently the $a_{i} s$ will represent prices. The most expensive commodity contributes the highest per unit welfare and vice versa. In the case of assets, respondents provide information on assets via discrete responses such as whether or not they own a particular asset; or from a list provided they pick the one that appropriately fits the type of asset they own. The data thus generated is categorical and $a_{i} s$ remain unidentified from surveys, unlike market prices.

One simple possibility is to assume all assets bear equal weight. Such an assumption, though simplifies immensely the computational requirements comes at a great cost. For instance, in the case of asset ownership, valuing owning a car in the same manner as owning a radio would simply imply that an individual is as well of owning a radio as a car. As a result of this assumption, it becomes also analytically difficult for data to discriminate adequately across welfare tiers defined over a set of assets. Researchers often rely on a statistical method to derive the weights from the data using what is commonly known as Factor Analysis or Principal Components Analysis (see Moser and Felton, 2007 for a good presentation of this approach). Both of these approach are data reduction methods that allow the researcher to pick the factor that most likely contributes to the overall variance of the ownership of assets across individuals. An intuitive argument in this context would be for instance a person who owns a car is very likely to own radio, perhaps tv, lives in a house provided with electricity and running water. Thus, among the list of assets, car ownership plays the pivotal role in discriminating across individuals into a set of distinct groups (such as poor, middle class and upper middle class). We apply this framework in this paper to generate the weights given in equation (1).

We specifically use Multiple Correspondence Analysis (MCA) which is closely related with factor analysis or principal components analysis. The only difference is the MCA is considered to be suitable for categorical variables (e.g.Booyseen, et al, 2008) ${ }^{2}$. In simple terms, if we denote $a_{j}$ the weight of category $j$ and $R_{i j}$ the answer of household $i$ to category $j$, then the asset index score of household $i$ is :

$$
M C A_{i}=\sum_{j=1}^{J} a_{j} R_{i j}
$$

This index can then be normalized between 0 and 1 to allow for intertemporal and cross country comparisons by the following formula

$$
\text { normalized_MCA } A_{i}=\frac{M C A_{i}-\min (M C A)}{\max (M C A)-\min (M C A)}
$$

1. $\frac{a_{i}}{a_{j}}=\frac{d c_{i}}{d c_{j}}$

2. See Sahn and Stifel (2000) for application of factor analysis to asset poverty in selected African countries. 
Once we have generated the asset index for each country from unit record data the next step is to identify the middle class. There is a growing literature that focuses on the definition of the middle class in the context of developing countries $^{3}$. Some focus on relative definition where the upper and lower bounds are a certain percentage of either the median or mean income (e.g. Birdsall, Graham and Pettinato, 2000). Others use absolute definition of a middle class such as individuals living below $2 \$$ and $10 \$$ per day (Banerjee and Duflo, 2008; Milanovic and Yitzhaki, 2002; Bhalla, 2008 and others) ${ }^{4}$. While each definition has some grounding, arbitrariness cannot be avoided. For the purpose of this study, the middle class is defined as those households that fall within the bounds of $50 \%$ to $125 \%$ of the median (weighted) asset index for the entire sample which is 0.5 and 0.7 and we kept this constant over time and of course across countries. In this sense, we are using an absolute measure of a middle class. There is a clear advantage of using an absolute measure of the middle class as it allows simple comparison across countries and over time with no ambiguity on aggregation within sub-gorups. But, this method has limitation in that the size of the middle class could shrink following a significant progress in living standards.

\subsection{Framework to understand the drivers of middle class}

What factors are closely associated with the making of the middle class? Some profile of the middle class based on observed individual and community/country characteristics could help greatly to enrich the discussion on the evolution of the middle class. In this study we have followed three approaches to undertake the exercise. The first is a comparison of the size of the middle class at a country level with a set of variables that have some resonance to the political economy literature, such as governance, ethnic diversity and mutual trust among citizens as drivers of the middle class. The second is the use of synthetic or pseudo-panels to analyze mobility in and out of the middle class as well as examine with some degree of robustness by controlling for unobserved time invariant factor an important aspect of promoting the middle class which is education and health of citizens ${ }^{5}$. The pseudo panel was set up from over 750000 observations spanning 42 countries with multiple waves. We used time-invariant characteristics such as age and sex of the individual to define a cohort and obtained 1337 individualcountry-period matched data. The third approach we followed is to use unit record data for the 42 countries in multiple waves to estimate the correlates

\footnotetext{
3. Eisenhauer (2007) reviews the literature on the definition of the middle class in the context of developed countries

4. See Ravallion (2010) for further discussion

5. See Verbeek (2007) for an excellent review of the properties of synthetic or pseudopanels.
} 
or determinants of the middle class by focusing mainly on individual characteristics (household size, age, sex and education level attained), spatial factors (region of residence) and unobserved factors (residuals) in a consistent way so that all individual histories were used to obtain comparable estimates across countries. Such decompositions as well as coefficients obtained from individual country or survey-level regression could provide some clue on the role of each factor in the making of the middle class. Additional data needed for the study was used from the following sources : ethnic fractionalization from Easterly and Levine (1997), trust and confidence, from the World Values Survey ${ }^{6}$, governance indicators from the International Country Risk Guide (ICRG) and Ibrahim Index provided by the Moi-Ibrahim Foundation, and macro indicators from AFDB data portal.

\section{Results}

\subsection{Evolution of the middle class in Africa}

The size of the middle class as defined by the asset index in Africa hovered around $11 \%$ for the 1990 s and $15 \%$ for the 2000 period $^{7}$ and overall increased steeply in the past two decades with notable variation across countries. During this period the Gini coefficient (weighted by population) for the asset index has also declined from $43 \%$ to $39 \%$ (see Figure 1 for the trend obtained from a non-parametric Lowess estimate). Combined these results provide some evidence of rising middle class at the regional level. This result is strikingly close to the estimates by $\operatorname{AfDB}(2011)$ of its conservative definition of the middle class based on consumption expenditure data from povcalnet.

The parallel between the consumption and asset based measures of the middle class extends also to the cross-country profile. As shown in Figure 2 there is strong correlation between the size of the middle class estimated on the basis of consumption expenditure from household surveys (povcalnet data) and asset-based measures from DHS with a correlation coefficient of about $66 \%$. This provides robustness to our result. The former is based on a definition of middle class as the percentage of the population with income between 5 and 10 in PPP per day per person.

The decade 2000 showed a substantial improvement in the size of the middle class in about 21 African countries some showing dramatic increases over time. Most of the countries that have shown rising middle class are also those that recorded sustained growth in the last decade, such as Senegal,

6. See http://www.worldvaluessurvey.org/

7. The mean was weighted by population 


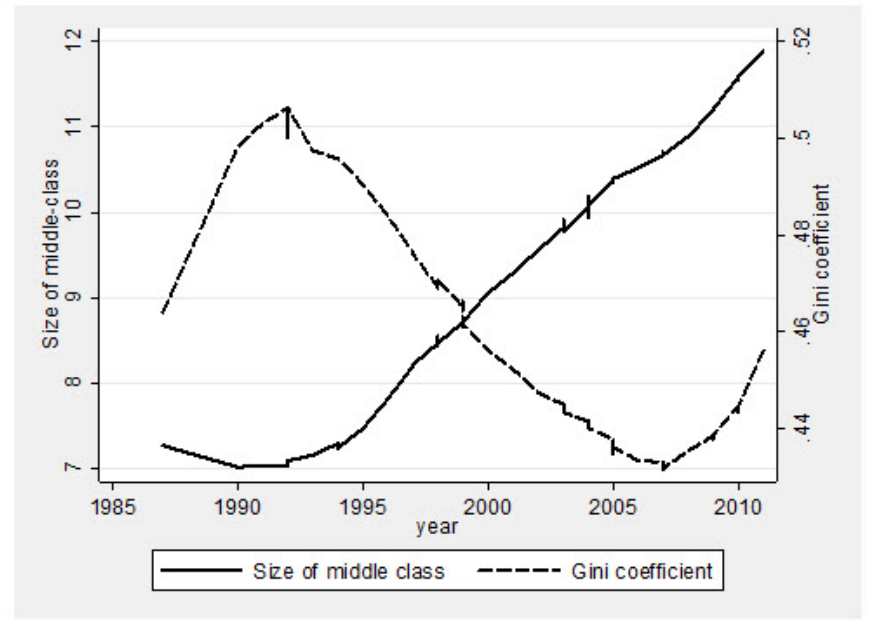

FiguRE 1 - Overall trend in the size of middle class and Gini coefficient in asset index

Kenya, Ghana and Nigeria.

A decline in the size of the middle class does not necessary follow from a rise in income inequality or an increase in the size of the poor population. We provide interesting comparisons on the evaluation of the middle class using unit record data for Egypt, Ghana and Madagascar based on DHS where each underwent different paths.

Figure (4) depicts a Kernel density for the evolution of the distribution of the asset index for Egypt between 2003 and 2008. It can be seen that the share of the middle class (those with an asset index lying between 0.5 and 0.7 ) has declined considerably even though asset poverty has declined as well as asset inequality (the Gini coefficient for 2003 was $13 \%$ while for 2008 it was 8\%). The experience of Egypt suggest that the middle class in 2003 graduated perhaps into what would be classified as "rich" and many who have been asset poor escaped poverty echoing a situation documented in the US during the 1980s (Daly, 1997). In this context, a shrinking middle class may be interpreted differently.

The experience of Ghana is a typical case as shown in Figure 5 where the size of the middle class expanded significantly, asset poverty declined and the Gini coefficient for asset also declined dramatically from $46 \%$ in 2003 to $38 \%$ in 2008. This is a pattern we would expect to happen in a situation where previously poor people join the ranks of the middle class in the process of development. 


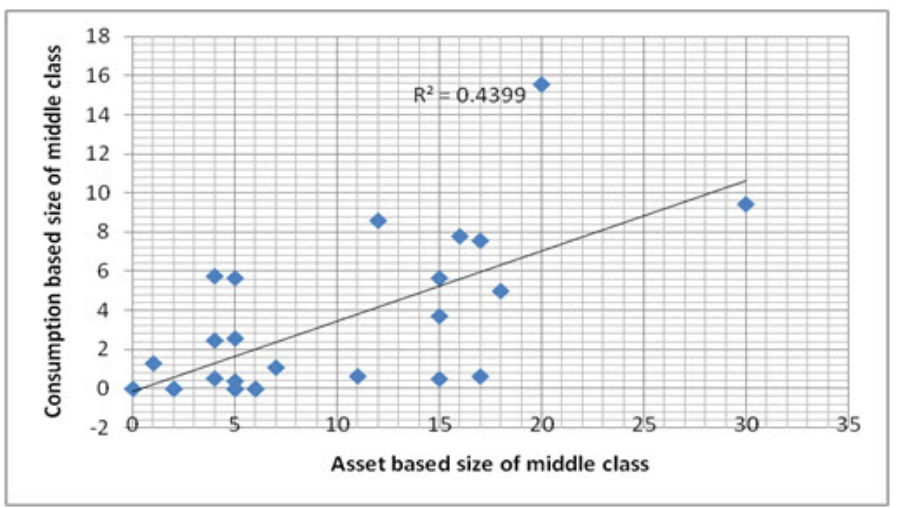

FiguRE 2 - Size of middle class based on consumption expenditure and asset

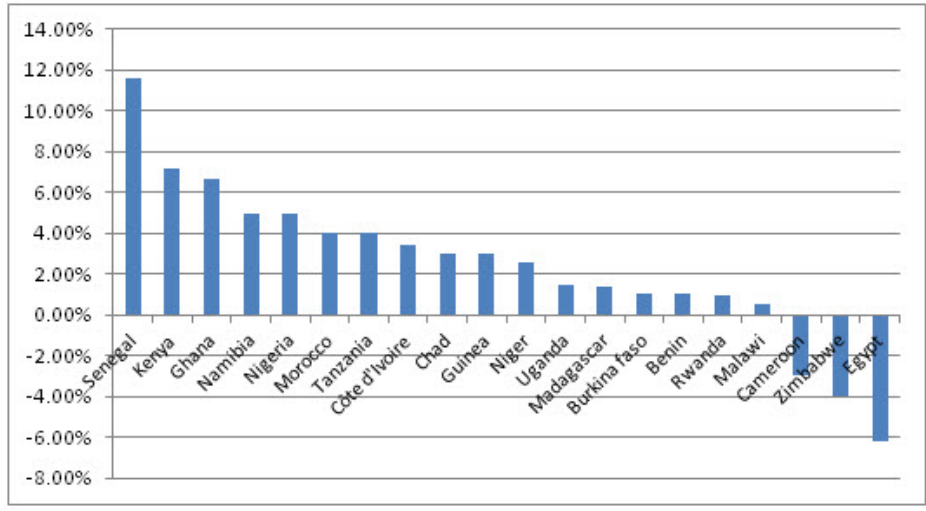

Figure 3 - Change in the size of the middle class (percentage point) in selected African countries (1990s and 2000s)

The experience of Madagascar is the exact opposite of Ghana or Egypt. The country experienced a rise in asset poverty and also inequality (Gini coefficient for asset increased from $42 \%$ in 2004 to $54 \%$ in 2009). There was a general deprivation where the mean asset index declined from 0.21 to 0.13 . The decline in the size of the middle class however was not large compared to the size of the poor population largely because a rise in inequality prevented the fall in the size of the middle class. In summary the interaction between asset poverty and inequality with regard to the size of the middle class is non-linear and several scenarios are possible as these three cases illustrate clearly. 


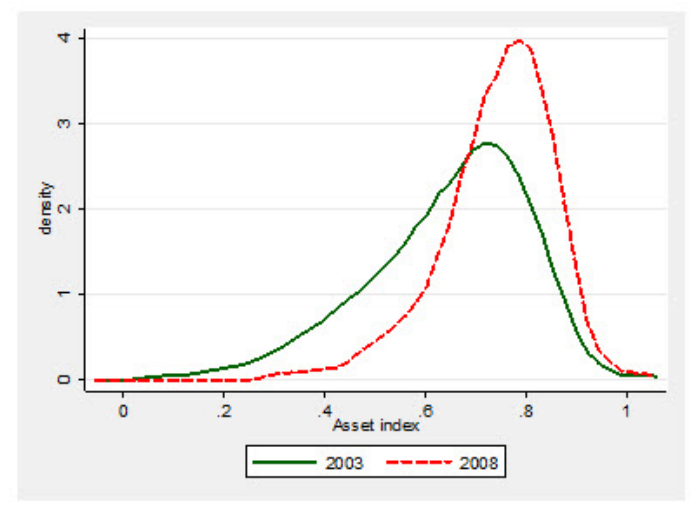

Figure 4 - Kernel density of Asset Index for Egypt

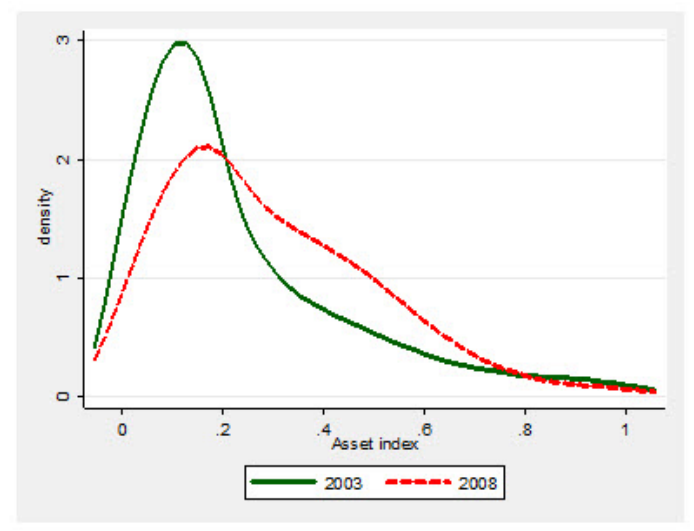

FiguRE 5 - Kernel density for Ghana

\subsection{Mobility into and out of middle class}

The trend in the size of the middle class is indicative of how the middle class evolved over time. It does not tell however how 'persistent' a middle class status would be once attained and also how easy it would be to climb back in an unfortunate situation once lost due to several factors such as temporary shocks. The nature of the dynamics is as important as the average trend as it offers insight into the possibilities for social mobility after hindered by structural as well as temporary setbacks. Often, accurate representation of social mobility can be drawn from real panel data where individuals are followed over a long period of time. In Africa such data is sparse. The only country for which the authors have access to such a data is Ethiopia where close to 1,500 households in urban areas were followed for over ten years during 1994-2004 for which information on middle class sta- 


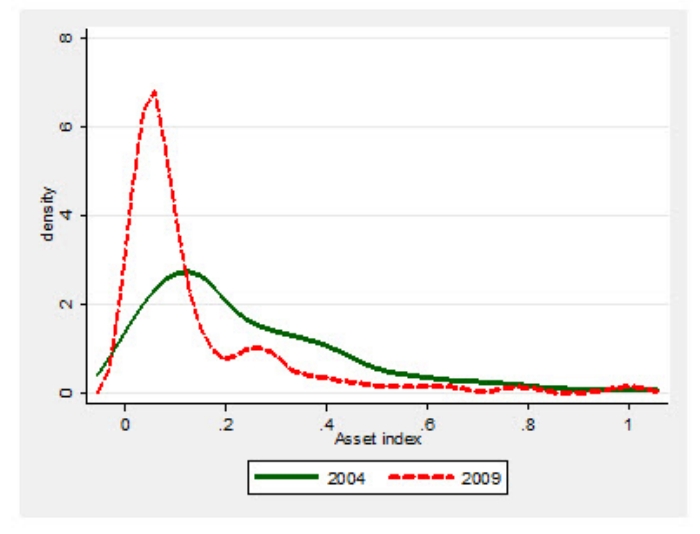

Figure 6 - Kernel density for Madagascar

tus (self-reported) is available to complement our analysis (see Bigsten and Shimeles, 2011, 2008 regarding the data). What we attempted in this paper is to construct a synthetic panel as fully described in the data section for all countries for which DHS data was available. 
One result that clearly emerges from the transition matrix reported in Table 1 is that on the average the probability that an individual would be asset poor in 2005-2011, regardless of his/her background in early 1990s was around $86 \%$, a middle class around $9 \%$ and an upper class around $4 \%$. Despite the encouraging trend that the size of the middle class increased over time, one could easily see the massive poverty prevalent in the continent. Fortune shifts with initial conditions dramatically. Those that started a middle class in early 1990s would have a $70 \%$ chance of staying that way while the bulk of them would graduate into the upper class. Very few (about 3\%) slip back into poverty. This result certainly is based on highly aggregated panel data and likely influenced by dynamics across than within countries. The upper class and the poor remained entrenched in their relative positions as in the early 1990s. The middle class status is the one that exhibited more churning than the other two extreme classes. The dimension of mobility takes a different twist when education and sex of the individual are taken into account. For individuals with no education, primary or secondary the situation is more or less similar where there was no middle class to start with in the early 1990s and in the late 2000 most attained middle class or upper class status signifying more of upper mobility for this cohort. For those with higher education, there was an $11 \%$ risk of becoming poor in the mid-2000 if they had been middle class in the early 1990s. The mobility to upper class was however much more pronounced. The picture from the synthetic panel certainly is less richer compared to real panel.

For an illustration Table 2 provides similar type of transition matrix for real panel for Ethiopian urban households based on self-reported class status. Interestingly, there was $70 \%$ chance of a household that started middle class to keep their status over ten years period. However, more people slipped into the poor category than those escaped into the upper income class. In addition, more people who started out in the upper class fell into poverty signifying important churning during the last decade. That may not be surprising. Ethiopia has undergone rapid economic, social and political changes during the period covered in the study and illustrates what could happen in societies in transition.

\subsection{Drivers of cross-country variations in the size of middle class}

\section{Initial conditions}

What factors drive cross-country variations in the size of the middle class in Africa? The answer could help also identify areas useful for public policy. It can be argued that the middle class thrive in the course of development. Given the absolute definition of the middle class that we adopted it is plau- 
TABle 1 - Transition Matrix for the poor, middle class and the rich : Pre1995-Mid-2000

\begin{tabular}{|c|c|c|c|c|}
\hline \multicolumn{5}{|l|}{ All Cohorts } \\
\hline & \multicolumn{4}{|c|}{$2005-2011$} \\
\hline Before 1995 & Poor & Middle class & Rich & Total \\
\hline Poor & 95.61 & 4.39 & 0 & 100 \\
\hline Middleclass & 2.33 & 69.77 & 27.91 & 100 \\
\hline Rich & 0 & 0 & 100 & 100 \\
\hline Total & 87.5 & 8.81 & 3.69 & 100 \\
\hline \multicolumn{5}{|c|}{ No Education } \\
\hline & \multicolumn{4}{|c|}{$2005-2011$} \\
\hline Before 1995 & Poor & Middle class & Rich & Total \\
\hline Poor & 94.59 & 5.41 & 0 & 100 \\
\hline Middleclass & 0 & 100 & 0 & 100 \\
\hline Rich & 0 & 0 & 0 & 0 \\
\hline Total & 92.45 & 7.55 & 0 & 100 \\
\hline \multicolumn{5}{|l|}{ Primary } \\
\hline & \multicolumn{4}{|c|}{$2005-2011$} \\
\hline Before 1995 & Poor & Middle class & Rich & Total \\
\hline Poor & 98.95 & 1.05 & 0 & 100 \\
\hline Middleclass & 0 & 73.33 & 26.67 & 100 \\
\hline Rich & 0 & 0 & 0 & 0 \\
\hline Total & 91.71 & 6.34 & 1.95 & 100 \\
\hline \multicolumn{5}{|l|}{ Secondary } \\
\hline & \multicolumn{4}{|c|}{$2005-2011$} \\
\hline Before 1995 & Poor & Middle class & Rich & Total \\
\hline Poor & 97.17 & 2.83 & 0 & 100 \\
\hline Middleclass & 0 & 61.54 & 38.46 & 100 \\
\hline Rich & 0 & 0 & 100 & 100 \\
\hline Total & 83.06 & 8.87 & 8.06 & 100 \\
\hline \multicolumn{5}{|l|}{ Tertiary } \\
\hline & \multicolumn{4}{|c|}{$2005-2011$} \\
\hline Before 1995 & Poor & Middle class & Rich & Total \\
\hline Poor & 60 & 40 & 0 & 100 \\
\hline Middleclass & 11.11 & 55.56 & 33.33 & 100 \\
\hline Rich & 0 & 0 & 100 & 100 \\
\hline Total & 33.33 & 36.67 & 30 & 100 \\
\hline \multicolumn{5}{|l|}{ Male } \\
\hline & \multicolumn{4}{|c|}{$2005-2011$} \\
\hline Before 1995 & Poor & Middle class & Rich & Total \\
\hline Poor & 95.19 & 4.81 & 0 & 100 \\
\hline Middleclass & 2.78 & 72.22 & 25 & 100 \\
\hline Rich & 0 & 0 & 100 & 100 \\
\hline Total & 84.8 & 10.45 & 4.75 & 100 \\
\hline \multicolumn{5}{|l|}{ Female } \\
\hline & \multicolumn{4}{|c|}{$2005-2011$} \\
\hline Before 1995 & Poor & Middle class & Rich & Total \\
\hline Poor & 96.43 & 3.57 & 0 & 100 \\
\hline Middleclass & 0 & 57.14 & 42.86 & 100 \\
\hline Rich & 0 & 0 & 0 & 0 \\
\hline Total & 93.1 & 5.42 & 1.48 & 100 \\
\hline
\end{tabular}


TABLE 2 - Transition matrix for self-reported wealth status in urban Ethiopia : 1994-2004

\begin{tabular}{llccc}
\hline & Rich & Middle class & Poor & \\
\hline Rich & $\mathbf{3 0 . 6 1}$ & 37.76 & 31.63 & 100 \\
Middle class & 3.16 & $\mathbf{6 8 . 5 1}$ & 28.34 & 100 \\
Poor & 1.57 & 26.63 & $\mathbf{7 1 . 8}$ & 100 \\
Total & 3.08 & 45.3 & 51.61 & 100 \\
\hline
\end{tabular}

sible to assume that initial conditions play a major role in explaining cross country variations. These include level of development (which is proxied here by the average per capita GDP between 1985 to 1990), size of government (proxied by share of government expenditure in GDP for the same year) and ethnic fractionalization which is an important element affecting economic and social mobility (Robinson, 2002) for several reasons either due to inherited differences in educational attainment or difficulty of redistribution (Glaeser, 2005). A recent study reported that controlling for a number of policy and economic factors, ethnicity remained a determinant of income inequality in Africa (Milanovic, 2003).

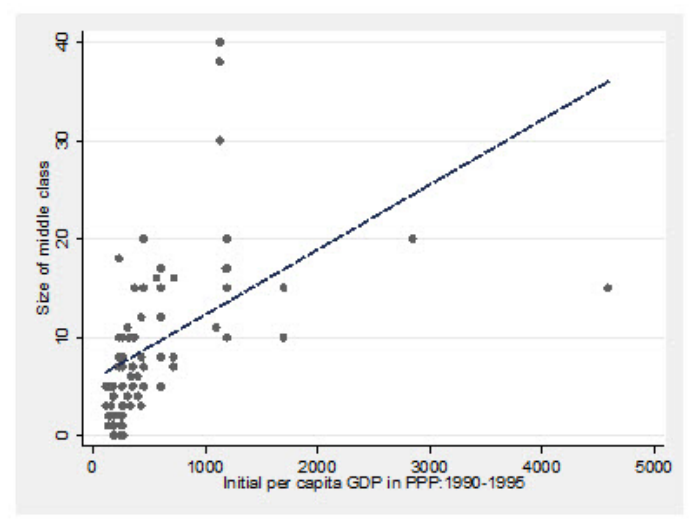

Figure 7 - Initial level of per capita GDP and size of the middle class in selected African countries

Results reported in Figure 7 provide some empirical support to the role of initial per capita GDP in affecting the size of the middle class. Relatively richer countries tend to have larger middle class. Again given the absolute definition of a middle class this result should not come as a surprise.

Countries with higher degree of ethnic, linguistic or cultural diversity 
could have high degree of inequality and thus smaller size of middle class. This is further complicated by weak institutions in Africa to put in place effective redistributive systems, as well as prevalence of ethnic based political dispensation. Figure (8) illustrates that the greater a country is ethnically divided, the lesser the size of the middle class becomes ${ }^{8}$. Given that ethnic diversity is difficult to change through public policies, it can be seen as a potential exogenous factor that prevents the growth of the middle class.

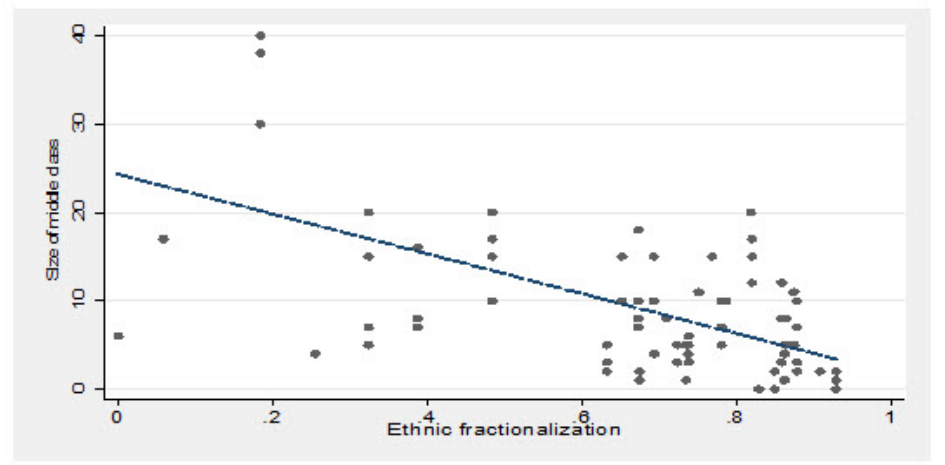

Figure 8 - Ethnic fractionalization and size of middle class in Africa

Finally, the level of inequality is an important factor driving the crosscountry difference in the size of the middle class. In Figure (9) we plot Gini coefficient for the asset index against the size of the middle class for countries in our sample. The strong negative relationship is suggestive of the fact that higher inequality in asset distribution is an impediment to the growth of the middle class.

Table (3) below decomposes the total variance in the size of the middle class into components that we believe are important in explaining the variations across countries. As can be seen, close to $73 \%$ of the total variation is explained by the level of the Gini coefficient, initial per capita GDP and ethnic fractionalization which is very large.

\section{Governance and human capital}

What can governments do to nurture the middle class in Africa? In the preceding section we noted that initial conditions and exogenous factors such as ethnicity play a significant role in driving cross country variations in the

8. The regression is based on OLS and does not take into account country level effects. The role of ethnic fractionalization remains robust in the case where we controlled for cohort as well as individual level effects. 


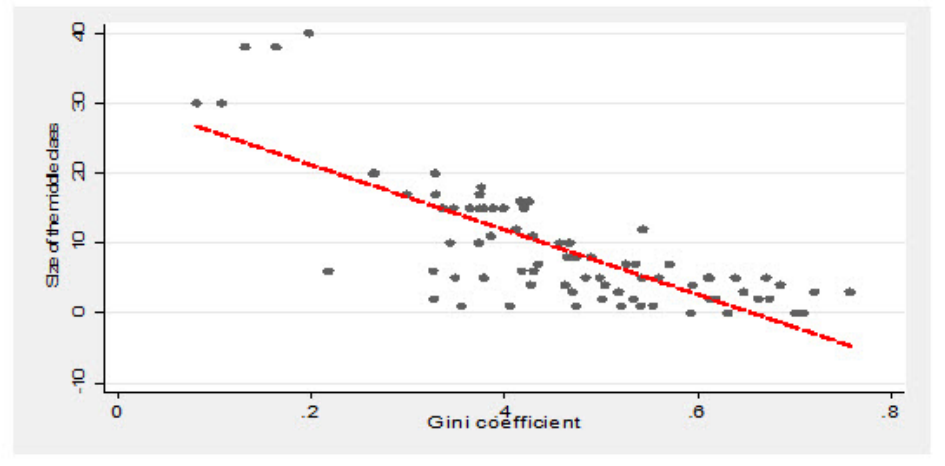

Figure 9 - Gini coefficient in asset index and size of the middle class in Africa

TABLE 3 - Regression based decomposition of variation in the size of middle class in Africa

Correlates of size of middle class $\quad$ Contribution to variance (\%)

Initial per capita GDP 81.3

Government expenditure as

a share of GDP (\%) 1.6

Gini coefficient for the asset index 33.3

Ethnic fractionalization $\quad-12.6$

Interaction between initial per

capita GDP and ethnic fractionalization $\quad-30.4$

Residuals $\quad 26.8$

Total 100

size of the middle class. Evidently that does not help much to policy. There is nothing one can do about initial conditions and number of ethnic groups in a country. It is possible to think of diverse ethnic groups in and of itself may not necessarily be a hindrance to social mobility. The catalyzing institutions that promote greater integration and trust among citizens remain to be important. In their seminal paper Zak and Knack (2001) analyzed and showed empirically the critical role trust plays in promoting growth through its effect on savings and investment. Given its potential importance, a trust variable was used as one of the factors correlated with the size of the middle class at country level. The results reported in Table 4 indicate that a one standard deviation improvement in the trust index is associated with a four percentage point increase in the size of the middle class. Given the small pace at which trust changes in a given country, the relation may be seen more in 
the context of understanding rather cross-country differences. There is also an issue of robustness. As will be shown below, the role of trust in affecting the asset index becomes statistically insignificant when disaggregated data were used and country level fixed effects were taken into account. It can be noted also that the role of ethnic fractionalization and governance at the cross-country level were rendered statistically insignificant by the presence of the Gini coefficient as one of the regressors. The reason could be that both affect middle class by worsening inequality. The synthetic panel data could be a richer source of establishing the link between the underlying welfare indicator and institutions.

TABLE 4 - Random-effects estimation of size of middle class on a set of correlates

\begin{tabular}{lcr}
\hline Variables & Coefficient & P-value \\
\hline Per capita GDP in 1985-1990 & $4.97 \mathrm{E}-05$ & $0.002^{* *}$ \\
Ibrahim Index & -0.00016 & 0.822 \\
Ethnic fractionalization & -0.04114 & 0.218 \\
Gini coefficient & -0.12182 & $0.035^{* *}$ \\
Trust level & 3.359491 & $0.009^{* * *}$ \\
period2 & -0.0062 & 0.625 \\
period3 & 0.017267 & 0.193 \\
period4 & 0.029075 & $0.013^{* *}$ \\
Number of observations & 86 & \\
Number of countries & 35 & \\
Overall R2 & 0.72 & \\
\hline
\end{tabular}

The literature on tackling inequality focuses on measures that enhance social mobility, such as rule of the law, property rights, institutions that promote equal opportunity (both market and non-market) and redistributive mechanisms. It is conceivable that economic and political governance feature very important in the case of African countries. This section presents some results on how governance can affect the size of the middle class in Africa by using the synthetic panel data. An obvious challenge is that as much as good governance promotes the emergence of middle class in a society, it is also possible that large middle class promotes governance or institutions. This reverse causality was investigated in Loayza, et al (2011) where they reported that large middle class could play an important role in reforming institutions. Our attempt to investigate the role of middle class for the African data set did not lead to any interesting result. A simultaneous equation in a three-stage least square framework relating governance indicator with the middle class and other covariate returned a result with 
a positive (right) sign but not statistically significant. Instead, the effect of good governance on the size of middle class remained robust, albeit with much reduced coefficient, after we controlled for cohort and country specific effects and used ethnic fractionalization as an instrument (see Table (5) ). This indeed is interesting in that part of the governance explained by ethnic fractionalization was able to affect the making of the middle class in Africa and implies efforts to improve overall governance conditions could pay off. We also note that the coefficient for ethnic fractionalization in this context remained significant with the right sign.

TABLE 5 - Random effects estimation of determinants of asset index

\begin{tabular}{lllcr}
\hline & \multicolumn{2}{l}{ Simple random-effects estimation } & \multicolumn{2}{l}{ Instrumental variable estimation } \\
\hline Variables & Coefficient & P-value & Coefficient & P-value \\
\hline Governance Index & 0.078574 & $0.000^{* * *}$ & 0.005399 & $0.042^{* *}$ \\
Sex is female & -0.05435 & $0.024^{* *}$ & -0.05423 & $0.029^{* *}$ \\
Primary complete & 0.412759 & $0.000^{* * *}$ & 0.414006 & $0.000^{* * *}$ \\
Secondary complete & 1.042552 & $0.000^{* * *}$ & 1.038307 & $0.000^{* * *}$ \\
Tertiary complete & 1.478252 & $0.000^{* * *}$ & 1.474945 & $0.000^{* * *}$ \\
Roher Health Index & $8.17 \mathrm{E}-05$ & $0.010^{* *}$ & $9.91 \mathrm{E}-05$ & $0.002^{* * *}$ \\
Initial per capita GDP & -0.02186 & $0.000^{* * *}$ & 0.000145 & $0.071^{*}$ \\
Ethnic fragmentation & -26.156 & $0.000^{* * *}$ & & \\
Country Dummies & Yes & & Yes & \\
Period dummies & Yes & & Yes & \\
Number of observations & 755 & $755^{\star}$ & & \\
Number of panel & 486 & 486 & & \\
Overall R2 & 0.9001 & 0.8973 & & \\
Hausman specification & & & & \\
test (Chi-2) & 62.73 & & & \\
\hline
\end{tabular}

The other more attractive and commonly accepted view is that education can be an important part of the making of the middle class. For this reason, we made some effort to capture its role at the country level and identify some patterns that may be useful for policy. We undertook a regression decomposition analysis of the asset index for 82 country-years using similar variables as correlates to allow us to make comparisons across countries. This has reduced our choice of variables. However, in all cases we regressed log of asset index on set of individual characteristics (age, family size, sex and educational attainment), and spatial variations to examine how education featured in the accumulation of assets. It was possible to infer that in at least a quarter of cases the share of education in explaining the variation in asset index was more than $25 \%$, which is quite significant and large ${ }^{9}$. Age,

9. The tables for the regression are more than three pages and thus could not be 
family size and sex explained only a fraction of the variation in the asset index while differences in region of residence in general contributed a substantial part specifically in large countries. The coefficients associated with primary, secondary and higher educations were invariably higher than the reference group (no education) for all countries (see Figure 8).

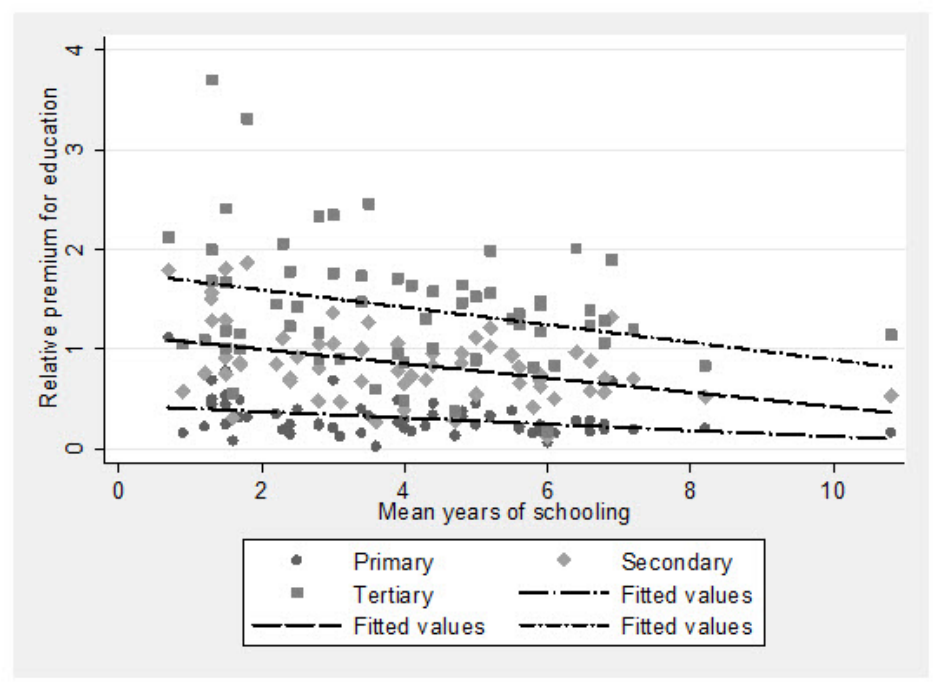

FiguRE 10 - Regression coefficients of education and mean years of education for African countries

Furthermore, the coefficients for each of the education levels showed a tendency of declining with the proportion of educated people as measured by mean years of schooling or proportion of population with corresponding level of education. This is interesting and needs to be sorted out to see the implications. Table (6) presents fixed-effect regression of coefficients for primary, secondary and higher education obtained from individual level regressions against two measures of the 'stock' of education in society. One is the proportion of people with primary, secondary and tertiary obtained from each survey used in the regressions. The other is mean years of schooling obtained from World Development Indicators as provided by the African Development Bank data portal. The trend exhibited in Figure 8 did not hold anymore for primary but remained robust for secondary and slightly for higher education. The downward trend in the 'returns' to education for secondary and higher education is suggestive of what could be interpreted as the decline in relative 'wages' as supply of labor increases. Ideally, relative inequality across the education spectrum tends to decline with development. At least

included in the text for brevity sake. 
from our result it can be inferred that countries with low stock of educated people could get a rapid gain in fostering middle class by investing in education, particularly secondary and higher education. Even in countries where the proportion of educated people is large, still the roles of education in acquiring assets remain important. Thus, for both types of countries, focus on education is helpful but also care should be made on its limitations. Education alone is not sufficient and needs to be matched with demand. 


\section{Conclusion}

This study provided some evidence on the size and pattern of middle class in Africa primarily using unit record data from 42 African countries spanning almost two decades. Using 11 different aspects of asset formation, which are the foundations of class differences, the paper constructed a composite asset index over different periods. The results are consistent with what $\operatorname{AfDB}(2011)$ estimated in a companion paper. The conservative estimate of the middle class in the late 2000 is about $15 \%$ up from $5 \%$ from the previous decade. The main reasons could be explained by a decline in the degree of inequality in asset ownership in many countries and progress in living standard in the last decade. The cross country correlation between asset and consumption based measure of middle class is also strikingly strong providing some level of comfort on results reported using both methods. Overall, most countries covered in our survey experienced a rise in the size of the middle class over the last decade. There were however some shrinking of the middle class. Some of it was for the right reason such as in Egypt where rapid expansion in asset ownership put a large percentage of previously middle class people into the upper class. In other cases it was because of rundown of asset as in the case of Madagascar. The experience of Ghana was ideal. The size of middle class increased because of increase in asset ownership as well as decline in inequality.

The main contribution of our paper comes from the use of synthetic panel merged from close to 750000 individual observations to analyze the dynamics of middle class status for four distinct periods starting from early 1990s, mid1990s, early 2000 and mid-2000. The results more or less confirmed what was observed in the trends. The probability of retaining a middle class status for those that started out as thus was around $70 \%$ which is quite significant. Close to $27 \%$ probability went for rising up in class and a fraction went for slipping back into poverty. The other striking result was that overall the probability of becoming poor during the entire period was around $88 \%$ while that of becoming a middle class was $9 \%$. Being in the upper class or rich was $3 \%$. This suggests a continent that is still struggling with widespread poverty and deprivation.

Cross-country variations in the size of the middle class are a result of mainly differences in initial level of per capita GDP, inequality in the asset index, ethnic diversity and to a certain extent lack of trust among citizens. The role of governance and education feature prominently in promoting the middle class in our discussion. Instrumented by ethnic fractionalization, good governance was associated with better asset ownership for our sample establishing some clear link between the two.

Education is found to be a very important factor in driving asset ownership. In more than $25 \%$ of the cases we investigated, the variation in the asset index due to education exceeded $25 \%$. In addition, the premium for 
education was evident across countries for primary, secondary and higher education levels. However, the premium or 'return' exhibited a decline for secondary and to a certain extent for higher education as the proportion of educated people increase. This is intuitive and also suggests that relatively skill scarce countries can accelerate the making of the middle class through investment in education. The fact that a declining 'return' to education is evidenced cautions from excessive investment in the sector. 


\section{References}

[1] Adelman, Irma and Cynthia Taft Morris. 1967. Society ,Politics, and Economic Development : A Quantitative Approach. Baltimore : Johns Hopkins University Press, Baltimore.

[2] AfDB (2011), "The middle of the pyramid : dynamics of middle class in Africa", memo.

[3] Barnerjee, A and Duflo, E. (2008), "What is middle class about the middle class around the world?", Journal of Economic Perspectives, 22(2) : $3-28$.

[4] Birdsall, N. (2010) "The (indispensable) middle class in developing countries; or the rich and the rest, not the poor and the rest, Center for Global Development, Working Paper 207.

[5] Birdsall, N., Graham, C., and Pettinato, S, (2000), "stuck in the tunnel : is globalization muddling the middle class" Center on Social and Economic Dynamics, Working Paper 14, Brookings Institutions, Washington DC.

[6] Birdsall, Nancy and Juan Luis Londoño, Asset inequality matters : an assessment of the World Bank's approach to poverty reduction. AMERICAN ECONOMIC REVIEW, PAPERS AND PROCEEDINGS 87, No. 2 :32-37, May 1997.

[7] Bigsten, A and Shimeles, A, (2011), "The persistence of urban poverty in Ethiopia : A tale of two measurements", Applied Economics Letters, First Published on : 27 January 2011(iFirst).

[8] Bigsten, A and Shimeles, A, (2008)"Poverty transition and persistence in Ethiopia" (2008), (with Arne Bigsten) World Development, vol. 36(9), pages 1559-1584, September.

[9] Booysen F., van der Berg, S., von Maltitz, M., and G. du Rand (2008), "Using an asset index to assess trends in poverty in seven sub-Saharan African countries," World Development, 36(6), 1113-1130.

[10] Chun, N. (2010), "Middle class size in the past, present and future : a description of trends in Asia", Asian Development Bank.

[11] Daly, M. C. (1997). The 'shrinking' middle class? Federal Reserve Bank of San Francisco Economic Letter, 7 March. 
[12] Desdoigts, A and Jaramillo, F (2009)Trade, demand spillovers, and industrialization : The emerging global middle class in perspective, Journal of international economics (79) : 248-258.

[13] Easterly, W. (2001), "The middle class consensus and economic development", Journal of Economic Growth, 6(4), 317-335.

[14] Easterly, William and Ross Levine (1997), "Africa's Growth Tragedy : Policies and Ethnic Divisions," Quarterly Journal of Economics.

[15] Eisenhauer, J.G (2008), "An Economic Definition of the middle class", For Soc Econ (2008) 37 :103-113.

[16] Glaeser, E.L. (2005), "Inequality", NBER Working Paper Series, WP 11511.

[17] Knack, Stephen \& Keefer, Philip, 1997. "Does Social Capital Have an Economic Payoff? A Cross-Country Investigation, "The Quarterly Journal of Economics, MIT Press, vol. 112(4), pages 1251-88, November.

[18] McKinzie Global Insituite, (2010), "Lion's on the move : the progress and potential of African economies".

[19] Landes, David. 1998. The Wealth and Poverty of Nations. Norton (New York, NY).

[20] Loayza, N, Jamele Rigolini and Gonzalo Llorente (2011), "Does middle class bring institutional reforms" IZA.

[21] Pressman, S, (2007), "The Decline of the Middle Class : An International Perspective", Journal of Economic Issues, Vol. XLI, pp-181-200.

[22] Ravallion, M. (2010), "The developing world's bulging (but vulnerable) middle class", World Development, 38 (4) : 445-454.

[23] Robinson, Brooks (2002), "Income inequality and ethnicity : an international view", World Bank, mimeo.

[24] Sahn, D. E., and D. C. Stifel (2000), "Poverty comparisons over time and across countries in Africa," World Development, 28(12), 2123-2155.

[25] Sridharan, E. (2004) "The Growth and Sectoral Composition of India's Middle Class : Its Impact on the Politics of Economic Liberalization", 
India Review, 3 (4) : 405-428.

[26] Verbeek, Marno (2007), "Pseudo-panel and repeated cross-sections", in L.Mátyás and P. Sevestre, eds., (2008), The Econometrics of Panel Data : Fundamentals and Recent Developments in Theory and Practice, Springer

[27] World Values Survey (2005) http ://www.worldvaluessurvey.org

[28] Zak, P.J and S. Knack (2001), " Trust and growth', The Economic Journal, $111: 295-321$. 


\section{Annexe}

TABLE 6 - List of countries for which DHS data was used in this study

\begin{tabular}{lrr}
\hline Country & Year & middle class size \\
\hline Angola & 2007 & 16 \\
Angola & 2011 & 18 \\
Benin & 1996 & 5 \\
Benin & 2001 & 6 \\
Burkina faso & 1993 & 4 \\
Burkina faso & 1999 & 4 \\
Burkina faso & 2003 & 5 \\
Cameroon & 1991 & 8 \\
Cameroon & 1998 & 8 \\
Cameroon & 2004 & 5 \\
CAR & 1995 & 0 \\
Chad & 1997 & 1 \\
Chad & 2004 & 4 \\
Comoros & 1996 & 6 \\
Congo Brazzaville & 2005 & 11 \\
Congo Brazzaville & 2009 & 11 \\
Congo Democratic Republic & 2007 & 5 \\
Côte d'Ivoire & 1994 & 12 \\
Côte d'Ivoire & 1999 & 15 \\
Côte d'Ivoire & 2005 & 17 \\
Egypt & 1995 & 40 \\
Egypt & 2000 & 38 \\
Egypt & 2003 & 38 \\
Egypt & 2005 & 30 \\
Egypt & 2008 & 30 \\
\hline
\end{tabular}


TABLE 7 - List of countries for which DHS data was used in this study

\begin{tabular}{|c|c|c|}
\hline Country & Year & middle class size \\
\hline Ethiopia & 2000 & 3 \\
\hline Ethiopia & 2005 & 5 \\
\hline Ethiopia & 2011 & 6 \\
\hline Gabon & 2000 & 15 \\
\hline Ghana & 1993 & 7 \\
\hline Ghana & 1998 & 8 \\
\hline Ghana & 2003 & 10 \\
\hline Ghana & 2008 & 18 \\
\hline Guinea & 1999 & 3 \\
\hline Guinea & 2005 & 6 \\
\hline Kenya & 1998 & 3 \\
\hline Kenya & 2003 & 8 \\
\hline Kenya & 2009 & 12 \\
\hline Lesotho & 2004 & 4 \\
\hline Lesotho & 2009 & 4 \\
\hline Liberia & 2007 & 2 \\
\hline Liberia & 2009 & 12 \\
\hline Madagascar & 1992 & 3 \\
\hline Madagascar & 1997 & 2 \\
\hline Madagascar & 2004 & 6 \\
\hline Madagascar & 2009 & 2 \\
\hline Malawi & 1992 & 1 \\
\hline Malawi & 2000 & 1 \\
\hline Malawi & 2004 & 2 \\
\hline Malawi & 2010 & 1 \\
\hline Morocco & 1987 & 10 \\
\hline Morocco & 1992 & 17 \\
\hline Morocco & 1995 & 15 \\
\hline Morocco & 2004 & 20 \\
\hline Namibia & 1992 & 10 \\
\hline Namibia & 2000 & 15 \\
\hline Namibia & 2007 & 15 \\
\hline Niger & 1992 & 3 \\
\hline Niger & 1998 & 2 \\
\hline Niger & 2006 & 5 \\
\hline
\end{tabular}


TABLE 8 - List of countries for which DHS data was used in this study

\begin{tabular}{|c|c|c|}
\hline Country & Year & middle class size \\
\hline Nigeria & 1999 & 10 \\
\hline Nigeria & 2003 & 15 \\
\hline Nigeria & 2008 & 15 \\
\hline Nigeria & 2010 & 15 \\
\hline Rwanda & 1992 & 0 \\
\hline Rwanda & 2000 & 2 \\
\hline Rwanda & 2005 & 0 \\
\hline Rwanda & 2010 & 7 \\
\hline Senegal & 1993 & 5 \\
\hline Senegal & 1997 & 7 \\
\hline Senegal & 2005 & 15 \\
\hline Senegal & 2009 & 20 \\
\hline Senegal & 2011 & 20 \\
\hline Sierra leone & 2008 & 4 \\
\hline South Africa & 1998 & 20 \\
\hline Sudan & 1990 & 11 \\
\hline Swaziland & 2007 & 17 \\
\hline Tanzania & 1992 & 1 \\
\hline Tanzania & 1996 & 1 \\
\hline Tanzania & 2005 & 5 \\
\hline Tanzania & 2010 & 5 \\
\hline Togo & 1998 & 8 \\
\hline Uganda & 1995 & 0 \\
\hline Uganda & 2001 & 2 \\
\hline Uganda & 2006 & 1 \\
\hline Uganda & 2009 & 3 \\
\hline Zambia & 1992 & 5 \\
\hline Zambia & 1996 & 10 \\
\hline Zambia & 2002 & 5 \\
\hline Zambia & 2007 & 7 \\
\hline Zimbabwe & 1994 & 13 \\
\hline Zimbabwe & 1999 & 16 \\
\hline Zimbabwe & 2006 & 11 \\
\hline Zimbabwe & 2011 & 10 \\
\hline
\end{tabular}

